\title{
PELATIHAN BAHASA INGGRIS DAN PENGENALAN TEKNOLOGI INFORMASI BAGI REMAJA BENGKONG KOLAM BATAM
}

\author{
Gaguk Rudianto \\ Universitas Putera Batam (UPB), Batam, Indonesia \\ e-mail: Gagukrudianto@gmail.com \\ Zia Hisni Mubarak \\ Universitas Putera Batam (UPB), Batam, Indonesia \\ e-mail: zia.hisni@puterabatam.ac.id \\ Winda Evyanto \\ Universitas Putera Batam (UPB), Batam, Indonesia \\ e-mail: winda731016@gmail.com \\ Mhd. Johan \\ Universitas Putera Batam (UPB), Batam, Indonesia \\ e-mail: thorshid@gmail.com \\ Sasa Ani Arnomo \\ Universitas Putera Batam (UPB), Batam, Indonesia \\ e-mail: sasa@puterabatam.ac.id

\section{Zakrimal} \\ Universitas Putera Batam (UPB), Batam, Indonesia \\ e-mail: zakrimamal@gmail.com
}

\begin{abstract}
This service activity is an activity in the form of training on English Conversation and Introduction to Information Technology for Youth in RT 02 RW 09, Bengkong Sadai Batam which is held at the Gedung Pertemuan RW09 Bengkong. The training held is a multi-disciplinary training or combines several study programs, especially English and Computer Study Programs. The training materials have been prepared in such a way that they are able to at least provide some solutions to the problems of the younger generation that are happening in the current millennial era. These problems include, among other things, teenagers in these neighborhoods do not master English and lack information technology. This training is carried out starting in November 2021 and ending in December 2021 with as many as 5 meetings held regularly. From this training, it is hoped that the training participants will get refreshed knowledge about the application of English and Introduction to Information Technology.
\end{abstract}

Keywords_-training, English dan information Technology 


\section{PENDAHULUAN}

Masa depan suatu negara akan sangat tergantung kepada keadaan atau kondisi pemuda di negara tersebut pada masa sekarang. Apabila keadaan pemuda di negara tersebut cukup baik hal ini dapat dilihat dari peran serta pemudanya dalam mengisi pembangunan dengan cara melakukan segala aktivitas sehari-harinya dilakukan dengan penuh dedikasi dan tanggung jawab maka dapat dipastikan kondisi pemuda yang demikian tersebut dapat dikatakan cukup baik dan sangat kondusif untuk melanjutkan tongkat estafet pembangunan Indonesia Raya yang bersinambungan hingga titik darah penghabisan

Peran serta pemuda dalam sejarah perkembangan dan perjuangan bangsa Indonesia sudah sangat terbukti dan tidak perlu diragukan lagi. Hal ini bisa kita lihat dari mulai dari tahun 1928 yang sudah dikenal dengan kelahiran "Sumpah Pemuda", dimana pada masa itu Pemuda-pemudi seantero Indonesia, mereka melepaskan identitas kedaerahannya demi menyatukan Gerakan nasional yang merupakan cikal bakal dari kemerdekaan dan persatuan Indonesia.

Perjuangan kemerdekaan pada masa itu hanya bersifat kedaerahan saja sehingga diperlukan suatu kekuatan yang luar biasa untuk menyatukan pemuda agar cita-cita bangsa pada zaman itu yaitu merdeka dari penjajahan Belanda dapat terwujud. Pergerakan ini dilai dari pendirian organisasi yang bersifat kedaerahan seperti Jong Java yang didirikan pada tahun 1915, Jon Soematranen Bond tahun pada 1917, dan Jong Islamieten Bond pada 1924. Pada tahun 1926 PPPI (Perhimpoenan Peladjar-Peladjar Indonesia) berhasil dibentuk. Organisasi kepemudaan ini adalah organisasi pertama yang keanggotaannya pelajar seluruh Indonesia. Pada tahun 1928 organisai-organisasi kedaerahan tersebut mengasilkan Kongres Pemuda II dengan menghasilkan Sumpah Pemuda yang awalnya diucapkan sebagai Sumpah Setia. Sebelum kongres ditutup, WR Supratman menampilkan lagu ciptaannya Indonesia Raya yang mendapat sambutan yang sangat meriah dari peserta kongres pada saat itu. Indonesia Raya kemudian menjadi lagu kebangsaan Indonesia yang menjadi identitas bangsa Indonesia.

Selanjutnya peran serta pemuda-pemudi Indonesia dalam perjuangan kemerdakaan Republik Indonesia juga memegang peranan yang sangat penting mulai dari berdiri di baris depan dengan mengangkat senjata melawan penjajah dengan hanya menggunakan persenjataan apa adanya seperti bambu runcing untuk melawan senjata penjajah yang modern pada jaman itu seperti tank dan lainnya. Sekali lagi berkat persatuan dan kesatuan pemuda Indonesia sebagai pelopor dan penggerak bangsa terbukti berhasil mengusir penjajah dari tanah air tercinta Indonesia.

Pada zaman milenial sekarang ini peran pemuda juga masih sangat diperlukan guna mengisi kemerdekaan. Peran tersebut berupa tantangan yang harus dihadapi dalam perkembangan teknologi dan informasi seperti menguasai teknologi tersebut serta menguasai Bahasa asing sebagai alat komunikasi di zaman milenial sekarang ini. Bahasa asing yang dimaksud adalah Bahasa Inggris. Menguasai Bahasa Inggris bukan tidak mungkin untuk direalisasikan dalam kehidupan yang serba modern saat ini. Namun berbagai kendala banyak ditemukan terutama dalam hal menguasai Bahasa Inggris dimana banyak orang yang mengatakan bahwa Bahasa Inggris ini susah untuk dipahami. Menurut Evyanto \& Mubarak (2020) kurangnya rasa percaya diri dalam diri setiap individu yang akan belajar Bahasa Inggris bisa berdampak terhadap kemampuan seseorang dalam menguasai Bahasa Inggris. Apabila seseorang memiliki rasa percaya diri yang tinggi, maka bukan tidak mungkin dia dapat menguasai Bahasa 
Inggris dengan lebih mudah. Namun sebaliknya jika seseorang memiliki rasa percaya diri yang rendah, maka sudah pasti semangat belajarnya pasti kendor. Menguasai Bahasa Inggris merupakan sebuah jalan menguasai teknologi terkini dimana Bahasa Inggris menjadi Bahasa yang dipakai secara universal dalam berbagai hal termasuk pengembangan teknologi.

Para pemuda dituntut untuk mampu beradaptasi dengan segala kecanggihan penemuan di zaman global sekarang ini. Celakanya penemuan peralatan canggih tersebut bagaikan dua sisi mata uang dimana di satu sisi ada suatu dampak yang positif namun di sisi lain dampak negatif juga tidak dapat dielakkan. Apalagi apabila keadaan pemuda-pemudi belum mempunyai filter yang cukup kuat untuk menyaring dari segala dampak negatif dari segala kecanggihan penemuan sekarang ini. Bukannya manfaat dari teknologi yang didapat tetapi malah pengaruh yang negatif akan menjadi suatu permasalahan yang cukup serius untuk ditangani.

Salah satu dampak negatif dari kemajuan jaman milenial sekarang ini adalah emosi dari para pengguna peralatan canggih seperti internet, HP dan lainnya. Hal ini bis kita lihat dari banyaknya permasalahan tentang dampaknya seperti ketidak sabaran, acuh, kurangnya hubungan sosial kemasyarakatan, pornografi, kecanduan handphone, belum lagi gangguan Kesehatan yang diakibatkan dengan radiasi komputer dan HP dan masih banyak lagi dampak yang cukup serius. Tidak salah kemudian Arnomo \& Siyamto (2021) mengatakan bahwa kemajuan teknologi berdampak besar terhadap kehidupan manusia.

Uraian tersebut diatas juga dialami oleh pemuda-pemudi di daerah Bengkong Kolam Batam dimana kebanyakan mereka belum begitu menguasai teknologi informasi, belum menguasai Bahasa Inggris sebagai Bahasa komunikasi global serta belum bisa menyaring dampak negatif dari kecanggihan alat komunikasi yang sudah menjadikan suatu kebutuhan pokok bagi mereka. Pelatihan Percakapan Bahasa Inggris, Pengenalan Teknologi Informasi dan Management Kecerdasan Emosi bagi Remaja ini dilaksanakan di lingkungan RT 02 RW 09 Kelurahan Sadai, Bengkong Kolam kota Batam.

\section{METODE}

Pengabdian adalah salah satu dari tridharma perguruan tinggi selain pengajaran dan penelitian. Sebagai seorang dosen pengabdian merupakan salah satu syarat untuk mendapatkan kepangkatan akademik. Dengan melaksanakan pengabdian diharapkan seorang dosen akan benar-benar menjadi manusia yang mampu bermanfaat dan mampu mewarnai kehidupan masyarakat.

Target keluaran daripada pengabdian ini adalah ditebitkannya laporan pengabdian di jurnal pengabdian. Dengan ditebitkannya laporan pengabdian ini maka diharapkan manfaat akan program yang dilakukan oleh pengabdi akan bermanfaat tidak hanya pada peserta didik, tetapi juga bermanfaat kepada seluruh anggota masyarakat terutama bagi pembaca yang membaca laporan pengabdian ini.

Adapun metode yang ditawarkan dalam memecahkan permasalahan yang dihadapi oleh remaja di lingkungan RT 02 RW 09 Kelurahan Sadai, Bengkong Kolam kota Batam adalah sebagai berikut:

1. Melaksanakan dialog dari hati ke hati untuk mengetahui permasalahan yang sedang mereka hadapi yang berhubungan dengan Bahasa Inggris, dan Teknologi Informasi.

2. Memberikan pelatihan Percakapan Bahasa Inggris dan Pengenalan Teknologi Informasi. 
3. Memberikan praktek dan Latihan untuk materi yang sudah diberikan.

4. Memberikan evaluasi atas kegiatan pelatihan dan

5. Mendiskusikan hasil pelatihan yang telah dilaksanakan.

\section{HASIL DAN PEMBAHASAN}

Remaja adalah salah satu aset bangsa yang sangat besar pengaruhnya terhadap keberlangsungan kehidupan bangsa dan negara karena ditangan merekalah nasib generasi selanjutnya bertumpu. Dengan berkembangnya teknologi informasi yang sangat canggih kita perlu mempersipkan remaja-remaja kita agar tidak menemui kendala dalam menghadapi persaingan global.

Agar mampu bersaing secara global maka diperlukan beberapa keterampilan yang bersifat aplikatif. Keterampilan tersebut adalah penguasaan percakapan bahasa Inggris, penguasaan informasi teknologi serta kemampuan mengelola kecerdasan emosi. Karena begitu pentingnya peranan tersebut maka materi yang disampaikan dalam materi pelatihan kali ini perlu dilakukan adanya tinjauan untuk keberlanjutan kegiatan pelatihan agar sasaran pelatihan benarbenar dapat tecapai dengan baik.

Kegiatan pelatihan ini ternyata juga mengundang simpatik dari beberapa warga dewasa yang juga hadir bersama warga remaja untuk mengikuti kegiatan yang mereka pandang sangat bermanfaat. Dari kegiatan pelatihan yang dilakukan bersama warga dewasa dan remaja tersebut didapatkan bahwa antusiasme belajar mereka masih terbilang tinggi. Hal ini mungkin dikarenakan para akdemisi memberikan bimbingan langsung secara gratis kepada warga dalam suasana yang informal, sehingga warga peserta pelatihan tidak merasakan beban berlebih ketika mengikuti pelatihan ini. Beberapa warga dewasa peserta pelatihan menyatakan bahwa ketertarikannya untuk mengikuti pelatihan ini adalah karena tuntutan kerja, dimana mereka bekerja di perusahaan asing yang ada di kota Batam dan mengharuskan mereka berkomunikasi dengan beberapa karyawan asing dengan menggunakan bahasa Inggris. Begitu juga dengan beberapa remaja yang ditanya, mereka mengakui ingin belajar bahasa Inggris agar mudah mencapai cita-cita dan bisa sukses di masa depan.

Tidak berbeda dengan bahasa Inggris, ketika materi tentang pengenalan teknologi informasi diberikan, banyak juga yang berkomentar dan menyampaikan pandangannya. Seperti pandangan dari beberapa warga dewasa yang sekaligus sebagai orang tua, mereka memiliki kekhawatiran terutama dengan berkembangnya teknologi informasi sekarang. Mereka mengkhawatirkan bahwa dengan teknologi yang semakin berkembang, banyak anak-anak yang nantinya terjebak oleh teknologi tersebut, dimana mereka hanya menikmati teknologi yang sedang dan terus berkembang ini seperti contoh yaitu sosial media. Anak-anak seperti terhipnotis oleh sosial media yang menyuguhkan konten-konten hiburan dan lebih tertarik untuk melihat sosial media daripada belajar. Hal yang sama juga terjadi ketika ditanyakan ke remaja bahwa beberapa dari mereka ada yang bercita-cita menjadi content creator atau youtuber. Dari sini kemudian tim pengabdi memberikan arahan kepada peserta dewasa agar dapat mengawasi anak-anak ketika memanfaatkan teknologi seperti handphone dan memberikan motivasi kepada peserta untuk melihat perkembangan teknologi dari sisi lain seperti halnya perkembangan dalam dunia kerja dimana pekerjaan baru banyak bermunculan akibat perkembangan teknologi.

Tim pengabdi kemudian memberikan beberapa saran kepada peserta pelatihan seperti: 
a. Belajar bahasa Inggris adalah sebuah keharusan agar dapat mengikuti perkembangan zaman.

b. Belajar bahasa Inggris tidaklah susah, yang susah adalah karena memikirkan bahasa Inggris itu susah sehingga timbul rasa kurang percaya diri.

c. Agar dapat maksimal belajar bahasa Inggris, tingkatkan dulu kepercayaan diri dan mulai menyukai bahasa Inggris dengan selalu berfikir positif terhadap segala tantangan yang diterima.

d. Agar dapat berkembang dengan baik, maka kita harus dapat menerima perkembangan teknologi informasi dengan sikap terbuka.

e. Hal-hal yang bersifat negatif dari perkembangan teknologi hendaknya disikapi dengan bijaksana yaitu dengan melihat kepada sisi positif dari perkembangan teknologi tersebut.

f. Perkembangan teknologi dan informasi adalah sesuatu yang pasti dan tidak dapat dibendung sehingga kita sebagai masyarakat harus melihat perkembangan era teknologi ini dari sisi lain seperti contohnya lapangan pekerjaan yang akan dihasilkan dari perkembangan teknologi ini.

Berikut adalah gambar yang diambil dari kegiatan pelatihan Bahasa Inggris dan Pengenalan Teknologi Informasi yang diselenggarakan di Gedung Pertemuan RW 09 Kelurahan Sadai, Bengkong Kolam kota Batam.

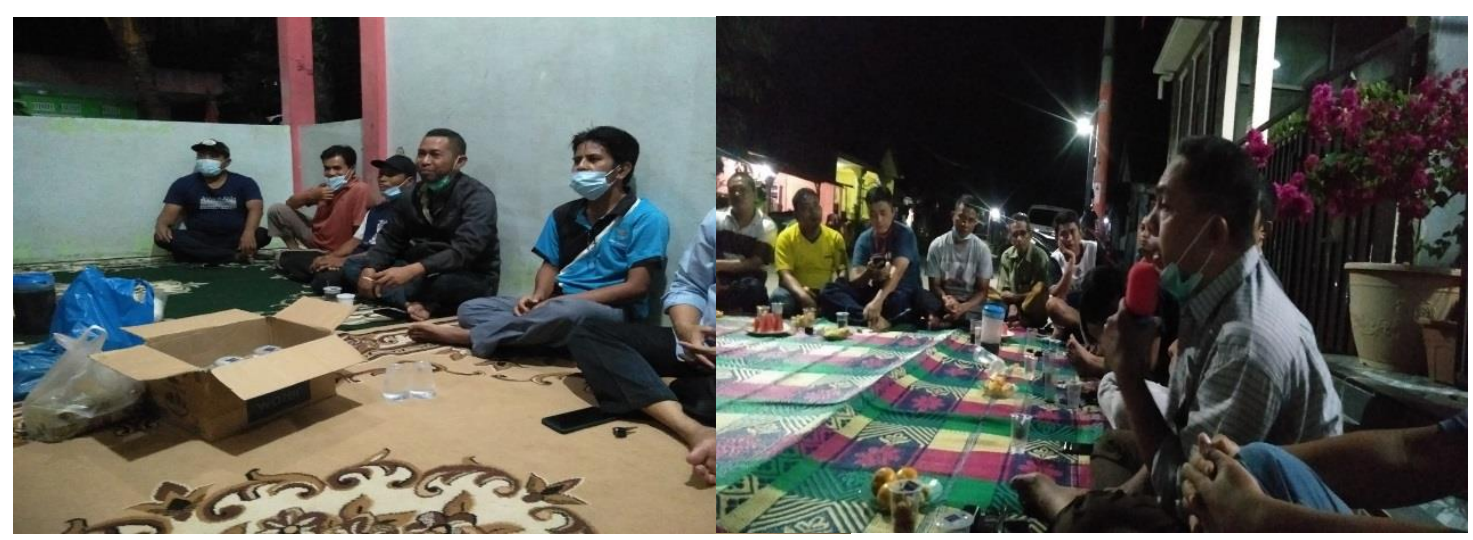

Gambar 1. Kegiatan Pengabdian bersama warga dewasa dan remaja Bengkong

Dari serangkaian kegiatan pelatihan yang telah dilakukan secara berkesinambungan diharapkan dapat meningkatkan minat belajar Bahasa Inggris dan meningkatkan pemahaman Pengantar Teknologi Informasi bagi remaja di lingkungan RT 02 RW 09 Kelurahan Sadai, Kecamatan Bengkong, Kota Batam.

\section{KESIMPULAN}

Mengingat peran serta remaja atau pemuda-pemudi dalam pembangunan di zaman milenial ini sangatlah penting maka dari kegiatan pelatihan tersebut dapat ditarik kesimpulan bahwa para peserta pelatihan masih memerlukan keberlanjutan dari pelatihan ini agar mereka mampu menguasai Bahasa Inggris praktis dan menguasai Pengenalan Teknologi Informasi secara lebih mendalam dengan harapan agar dapat bersaing di bursa kerja baik regional maupun global. 


\section{SARAN}

Bagi peserta pelatihan diharapkan untuk dapat menerapkan keseluruhan materi yang telah disampaikan dan kalau diperlukan mencari pelatihan lainnya dan kalau bisa melanjutkan Pendidikan ke jenjang yang lebih tinggi. Sedangkan bagi para pemateri diharapkan untuk senantiasa tidak merasa bosan dan enggan dalam memberikan materi kepada masyarakat sebagai perwujudan salah satu unsur tridharma perguruan tinggi

\section{UCAPAN TERIMA KASIH}

Penulis mengucapkan terima kasih kepada Lembaga/Instansi pemerintahan daerah seperti Ketua RW 09, Ketua RT 02, seluruh Pemateri, seluruh civitas akademika Universitas Putera Batam dan terutama kepada semua peserta pelatihan ini.

\section{DAFTAR PUSTAKA}

Alwisol. 2012. Psikologi Kepribadian. Malang. UMM Press

Andi, Mappiare. 1982. Psikologi Remaja, Surabaya. Usaha Nasional

... 2003. Himpunan Peraturan Perundang-Undangan Guru dan Dosen yang dilengkapi dengan Undang-Undang RI No 20

Arnomo, S. A., \& Siyamto, Y. (2021). Pelatihan Pemanfaatan Teknologi Informasi Pada Masyarakat Di Kelurahan Belakang Padang Kecamatan Belakang Padang Kota Batam. Puan Indonesia, 2(2), 103-112. https://doi.org/10.37296/jpi.v2i2.34

Evyanto, W., \& Mubarak, Z. H. (2020). Pembinaan Percakapan Bahasa Inggris Bagi Masyarakat Perumahan Griya Batu Aji Asri Batam. Puan Indonesia, 1(2), 89-94. https://doi.org/10.37296/about.v1i2.14 